\title{
Habitat and community structure modulate fish interactions in a a neotropical clearwater river
}

Correspondence:

Lucas Teixeira Nunes nuneslteixeira@gmail.com

\author{
$\odot$ Lucas T. Nunes ${ }^{1}, \oplus$ Renato A. Morais ${ }^{1,2}$, $\odot$ Guilherme O. Longo ${ }^{3}$, \\ -José Sabino ${ }^{4}$ and ${ }^{\oplus S e r g i o ~ R . ~ F l o e t e r ~}{ }^{1}$
}

Submitted November 18, 2019

Accepted February January 6, 2020

by Eliane Gonçalves de Freitas

Published April 20, 2020
Species interactions can modulate the diversity and enhance the stability of biological communities in aquatic ecosystems. Despite previous efforts to describe fish interactions in tropical rivers, the role of habitat characteristics, community structure, and trophic traits over these interactions is still poorly understood. To investigate among-habitat variation in substratum feeding pressure and agonistic interactions between fishes, we used remote underwater videos in three habitats of a clearwater river in the Central Western, Brazil. We also performed visual surveys to estimate the abundance and biomass of fishes and proposed a trophic classification to understand how these variables can affect fish interactions. Community structure was the main factor affecting the variation in the interactions among the habitats. Biomass was the main variable determining which habitat a fish will feed on, while species abundance determined with how many other species it will interact in the agonistic interaction networks for each habitat. Specific habitats are not only occupied, but also used in distinct ways by the fish community. Overall, our results demonstrate the importance of the heterogeneity of habitats in tropical rivers for the interactions performed by the fishes and how the intensity of these interactions is affected by community structure.

Keywords: Bodoquena plateau, Centrality, Characidae, Feeding pressure, Habitat heterogeneity.
Online version ISSN 1982-0224

Print version ISSN 1679-6225

Neotrop. Ichthyol.

vol. 18, no. 1, Maringá 2020

Epub, Apr 17, 2020
1 Laboratório de Biogeografia e Macroecologia Marinha, Departamento de Ecologia e Zoologia, Universidade Federal de Santa Catarina, Rua Engenheiro Agronômico Andrei Cristian Ferreira, s/n, Trindade, 88040-900 Florianópolis, SC, Brazil. (LTN) nuneslteixeira@gmail.com, (SRF) sergiofloeter@gmail.com

2 College of Science and Engineering, James Cook University, 1 James Cook Dr, QLD 4811 Townsville, Australia. renato.morais@my.jcu.edu.au

3 Laboratório de Ecologia Marinha, Departamento de Oceanografia e Limnologia, Universidade Federal do Rio Grande do Norte, Av. Senador Dinarte Mariz, s/n, Mãe Luiza, 59014-002 Natal, RN, Brazil. guilherme.o.longo@gmail.com

4 Programa de Pós-Graduação em Meio Ambiente e Desenvolvimento Regional, Universidade Anhanguera-Uniderp, Avenida Ceará, 333, Vila Miguel Couto, 79003-010 Campo Grande, MS, Brazil. sabino-jose@uol.com.br 
Interações realizadas por peixes podem modular a diversidade e assegurar a estabilidade de comunidades em rios tropicais. Apesar dessa importância, poucos estudos relacionam as interações ecológicas com as características do habitat, estrutura da comunidade e atributos das espécies de peixes. Por meio de filmagens remotas subaquáticas nós verificamos como a pressão alimentar dos peixes sobre a comunidade bentônica e as interações agonísticas entre peixes são influenciadas por essas características do habitat e da comunidade em um rio tropical de água clara na região Centro-Oeste do Brasil. Também realizamos censos visuais para estimar a abundância e a biomassa dos peixes e propusemos uma classificação funcional para entender como essas variáveis podem afetar as interações dos peixes. A estrutura da comunidade foi o principal fator que afetou a variação nas interações entre os habitats. A biomassa dos peixes determinou em qual hábitat um peixe se alimentará, enquanto a abundância das espécies determinou com quantas outras espécies elas interagem nas redes de interações agonísticas de cada habitat. Habitats específicos não são apenas ocupados, mas também utilizados de maneiras distintas pela comunidade de peixes. Nossos resultados demonstram a importância da heterogeneidade de habitats para as interações realizadas pelos peixes em rios tropicais e como a intensidade dessas interações é afetada pela estrutura da comunidade.

Palavras-chave: Centralidade, Characidae, Heterogeneidade de habitats, Pressão alimentar, Serra da Bodoquena.

\section{INTRODUCTION}

Tropical rivers often encompass high habitat-heterogeneity along their course (Vannote et al., 1980). These habitats are characterised by physical and biological features that promote distinct structural complexity (Bell et al., 1991), which can explain gradients of species diversity for freshwater organisms. As a result, the distribution of many organisms within a river can closely reflect habitats characteristics (Bell et al., 1991; Petry et al., 2003). For instance, small invertebrates and fishes that would otherwise be exposed to predation in low complexity habitats can find refuge in highly complex habitats, such as those formed by aquatic plants (Gorman, Karr, 1978; Coull, Wells, 1983; Savino, Stein, 1989; Sabino, Zuanon, 1998; Smith et al., 2014). Indeed, impaired visual contact between individuals in structurally complex habitats might reduce detectability (Bell et al., 1991), thus reducing the frequency of visually oriented interactions in general, not only during predation. These visually-mediated interactions are thought to be particularly common in clear water rivers and lakes (Bergman, Moore, 2003; Ranåker et al., 2014).

Habitat characteristics, such as three dimensionality and food resource availability, and species traits, such as morphological and behaviour adaptations, can directly affect the intensity and outcomes of biological interactions (Crowder, Cooper, 1982; Baber, Babbitt, 2004). For instance, prochilodontid fishes use their thick, fleshy and often 
suctorial lips to scrape the substratum, feeding on detritus and periphyton (Bowen, 1983; Power, 1983; Taylor et al., 2006). As a result, these fishes would be expected to be particularly abundant on habitats that offer such conditions, such as those with rocky and sand bottoms instead of macrophyte banks. In addition to habitat and species traits, species abundance can also play an important role on species interactions because abundant species tend to interact more intensely and with more components than rare ones (Vázquez et al., 2007).

Freshwater fishes are conspicuous components of tropical rivers, where they perform a variety of interactions (e.g., Sabino, Sazima, 1999; Taylor et al., 2006). The structure of their interaction networks is, however, not well understood, particularly because of limitations in water transparency that are critical to in situ observation of species interactions (Moss, 2010). When these conditions are met, observational studies have revealed a myriad of behaviours that are analogous to marine reef systems (e.g., Sazima, 1986). Many of these newly described behaviours and interactions, have important energetic consequences for the ecosystems in which they take place (e.g., Sazima, 1983; Sazima, 1986; Sazima, 1988; Sabino, Zuanon, 1998; Lima et al., 2012). More recently, technological advances (i.e., remote filming) have helped scientist to better understand the structure of freshwater fish assemblages and the interactions in which they engage (Ebner, Morgan, 2013; King et al., 2018).

In this study, we used remote underwater videos (RUVs) to quantify trophic and agonistic interactions of fish species in a highly diverse clearwater neotropical river. Specifically, we evaluated how these interactions are dependent on fish community structure (i.e., species-level density and biomass), habitat characteristics and species traits. We hypothesized that species traits and abundance, as well as habitat particularities, will modulate differences in trophic and agonistic interactions among habitats. We also hypothesized higher interaction intensity in visually low complexity habitats. Studies in these systems can help us to understand the importance of biological interactions in shaping species distributions and their energetic links in tropical freshwater river systems.

\section{MATERIAL AND METHODS}

Study area. Sampling was carried out in May 2011 at the Olho d'Água River, a tributary of the Miranda River in the upper Paraguay basin, state of Mato Grosso do Sul, Brazil (Fig. 1). Located in a Private Reserve of Natural Heritage (fishing is not allowed), this river is directly affected by the karstic geomorphology of the Bodoquena Plateau and the horizontal water transparency is often greater than 40 metres. Along its two kilometres of extension, the Olho d'Água River comprises habitats that vary in their physical features and biological components, but that are subject to near constant temperatures $\left(23-25^{\circ} \mathrm{C}\right.$ ) and water volume throughout the year (Manço, Pivatto, 2007; Teresa et al., 2014). In this river, we sampled three habitats that differed in substratum physiognomy (see Fig. 1, https://www.youtube.com/watch?v=RN5ohX7inME): the "Riverine lake" (further referred as "Lake"), which is a $600 \mathrm{~m}^{2}$ and $3 \mathrm{~m}$ deep lentic habitat located in the upper portion of the river, with a substratum covered by filamentous cyanobacteria, gravel and sand; the "Plant habitat", a lotic and shallow ( 1m deep) habitat presenting medium water flow where the substratum is covered by patches of 
macrophytes, mostly Heteranthera zosterifolia (Mart.) and Myriophyllum aquaticum (Vell.) Verdc., filamentous cyanobacteria, and sand; and the "Rock habitat", which is also lotic with slow-to-medium water flow and substratum mainly covered by stones, gravel, sand and twigs.

Sampling procedure and analyses. To assess fish abundance and biomass we performed 10 underwater visual censuses (UVCs) in each habitat, with no overlap among sampled areas. This method consisted of a belt transect in which a free diver
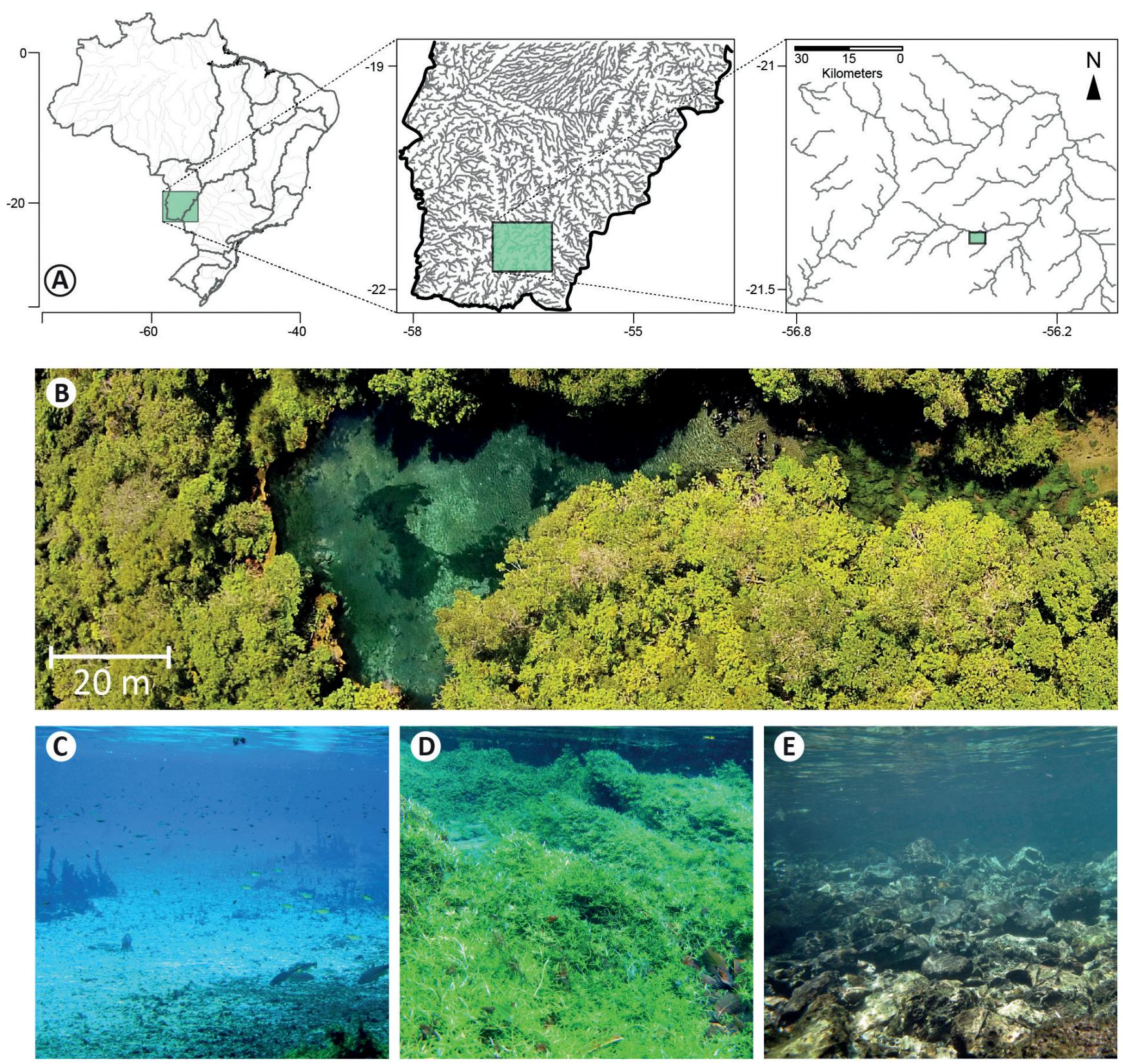

FIGURE 1 I A. Olho d'Água River located in the upper Paraguay River basin, Central Western Brazil. B. Note that clear water allows observation of the underwater vegetation even in aerial photographs. Three sampled habitats are: C. Lake; D. Plant; and E. Rock. 
swam in a constant velocity and identified, counted, and estimated the total length of fishes within a $40 \mathrm{~m}^{2}$ area $(20 \times 2 \mathrm{~m})$. To assess fish feeding and agonistic interactions, we recorded 14 diurnal Remote Underwater Videos (RUVs) in each habitat, between 0900 and 1600 hours, totalling 42 videos. Videos were recorded with a digital camera on a weighted tripod focused on $2 \mathrm{~m}^{2}$ areas of the substratum established with a measuring tape that was then removed before each recording. The minimum distance among recorded areas was three meters. Each $2 \mathrm{~m}^{2}$ area was recorded for $15 \mathrm{~min}$ and the central $10 \mathrm{~min}$ of each video was analysed in laboratory. Both visual surveys and RUVs methods were adapted from previous studies in reef systems (i.e., Longo et al., 2014, 2015; Morais et al., 2017) and demonstrated to be effective to record the community structure and feeding rates of fish assemblages, respectively. Furthermore, both methods are non-lethal for fishes and RUVs have the advantage of keeping the record for the confirmation of species identification and accurately quantifying interactions that may be difficult to count in the field (Longo, Floeter, 2012; Ebner, Morgan, 2013; Ebner et al., 2015).

In the video analyses, we identified each individual fish that bit the substratum or chased another fish inside the RUVs' focal area. The number of bites in the substratum of each fish individual was counted and its total length $(\mathrm{cm})$ estimated based on the measuring tape that was initially deployed. A bite was defined as the moment when a fish hits the substratum with its jaw open, with or without intake (Longo et al., 2014). We used the number of bites on the substratum and the total length of each individual to calculate their feeding pressure (FP) following the equation: $\mathrm{FP}=($ bites * biomass) / ( $2 \mathrm{~m}^{2 \star} 10 \mathrm{~min}$ ) (Longo et al., 2014). For each video (i.e., sample) we obtained the feeding pressure of each fish species from the sum of the feeding pressure of all individuals of each species. The individual biomass (B) was calculated based on the equation: $\mathrm{B}=\mathrm{a}^{\star}\left(\mathrm{TL}^{\star} \mathrm{CF}\right)^{\mathrm{b}}$, where $T L$ is the total length (centimetres), $a$ and $b$ are parameters of length-weight relationships and CF is a correction factor that rescales length-weight parameters obtained for standard length to the working measure total length (Tab. 1).

Fish species were assigned into trophic groups based on their feeding mode/ behaviour, obtained from in situ observations and RUVS, and diet obtained from the literature (Tab. 1). When data for a given species was not available, we used the trait of a congeneric species that had similar morphology and likely similar feeding behaviour. This classification resulted in eight trophic groups:

Grazing detritivores: Bottom-dwelling fishes that forage mostly on sand and rock substrate and have morphological adaptations to scrape the substratum (e.g., labial teeth). These fish sort the sediment in their oral cavity, retain organic detritus and eliminate inorganic matter such as sand (Bowen, 1983). They can ingest a large amount of detritus and sediment, and small portions of plant material and benthic invertebrates.

Grazing periphytivores: Bottom-dwelling fishes that forage over hard substratum such as rocks, fallen trees and twigs, and have morphological adaptations to scrape periphyton (Power, 1983). A small portion of detritus and plant material can also be part of the diet of this group. 


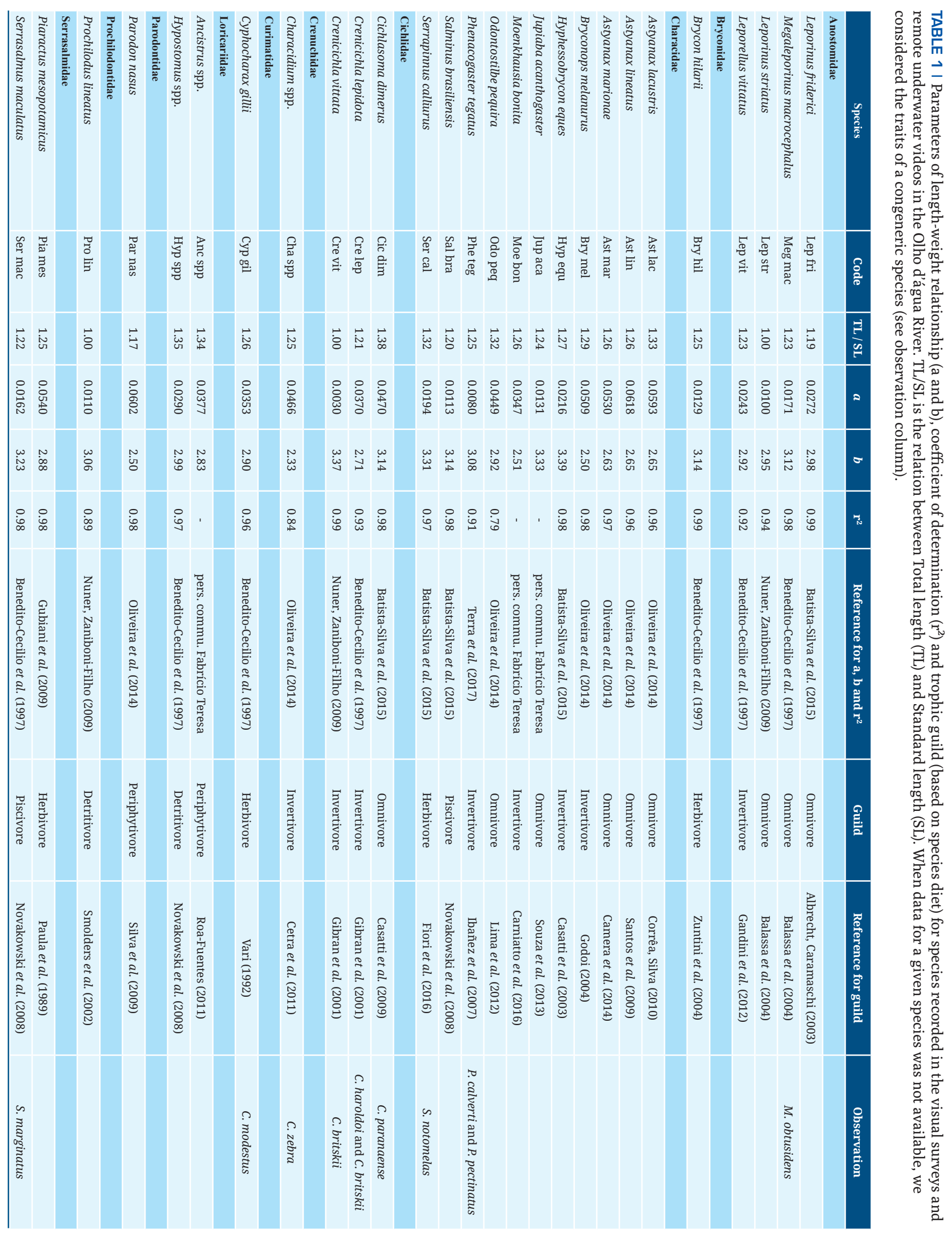


Browsing herbivores: Fishes that browse pieces of macrophytes and macroalgae (Sazima, 1986), as well as allochthonous material such as leaves, seeds and fruits.

Digging omnivores: Bottom-dwelling fishes that excavate the sandy substrate ingesting plant parts (including roots) and buried invertebrates, commonly attracting follower fishes by revolving the sediment (Sazima, 1986).

Nibbling omnivores: Bottom-dwelling fishes that ingest both animal (e.g, invertebrates) and vegetable items (e.g., seeds and macrophytes), taking small bites on the substratum (Sazima, 1986). They commonly bury a part of their snouts in the substratum but causing minimum bottom disturbance (Teresa et al., 2014).

Nibbling invertivores: Bottom-dwelling fishes that behave similarly to nibbling omnivores but rarely, if ever, ingest vegetable matter.

Picking omnivoress: Water column fishes that pick items on the surface, water column, commonly ingesting leaves, seeds, other plant fragments and small invertebrates (Sazima, 1986).

Picking invertivores: Water column fishes that behave similarly to picking omnivores but rarely, if ever, ingest vegetable matter.

We considered as agonistic interactions, both intra and interspecific events in which a fish chased another one without any obvious feature that could be associated to predation. Predation features could be 1) large size disparities, with the chaser fish much larger than the chased one, or 2) a deliberate bite was observed, such as when mucus or scales are targeted (Curio, 1976; Sazima, 1983; Lima et al., 2012). This last interaction, also called mutilating predation, can be easily distinguished because the chased fish appears unaware, fleeing only after physical contact (Lima et al., 2012), while in an agonistic interaction the chased fish flees as a response to the chaser's movement.

Statistical analyses. To assess whether our categorical classification of habitat was able to capture environmental heterogeneity, we used a principal coordinate analyses (PCoA) and a permutation analysis of variance (PERMANOVA), with Euclidean distance matrix obtained from nine environmental variables (response variables) visually estimated from the videos (samples) and subsequently transformed by standardization. These were: 1-5) percent cover of cyanobacteria, macrophytes, rock, gravel and sand; 6-7) height of macrophytes and height of the filamentous cyanobacteria; 8) presence or absence of twigs near or inside the RUVs area; and 9) maximum depth of each habitat. To check if habitats differed according to fish abundance or biomass (i.e., parameters of community structure) we used the UVCs as samples and performed a PCoA and a PERMANOVA analysis with Bray-Curtis similarity. The null hypothesis for this analysis was that habitats are not different in terms of fish community structure.

To check for differences in the feeding pressure (response variable) of fish species and trophic groups among the habitats (factor), we used the RUVs as samples to 
perform a PCoA and a PERMANOVA analysis with Bray-Curtis similarity. This was used to test the null hypothesis that habitats are not different regarding this feeding interaction. To relate the degree of centrality of a species in the agonistic interaction network to its average abundance (ind. / 40 $\mathrm{m}^{2}$ ) we performed a linear regression model for each habitat. Species centrality was obtained through the "degree centrality", which indicates the central node (i.e., species) in the networks accounting for the number of connections (i.e., agonistic interactions) with other species. The degree centrality of a given species (sample) in each habitat was obtained by summing the number of species that were chased and number of chaser species in the habitat.

To test the influence of species (sample) average biomass $\left(\mathrm{kg} / 2 \mathrm{~m}^{2}\right)$, average abundance (ind. / 40 $\mathrm{m}^{2}$ ), habitat and trophic group on the average feeding pressure and centrality in the agonistic interactions, we performed a generalized linear model with Gaussian distribution. A F test through the function drop1 of the package "car" (Fox, Weisberg, 2011) was used to evaluate significance. Abundance/biomass, feeding pressure and centrality were natural log transformed to decrease data dispersion. All the analyses and graphics were performed using "ggplot2" (Wickham, 2016), "gridExtra" (Baptiste, 2017), "plotrix" (Lemon, 2006), "reshape” (Wickham, 2007), "scales” (Wickham, 2017) and "vegan" (Oksanen et al., 2018) packages of R software version 3.4.3 (R Core Team, 2019). All data and R code can be downloaded from the Zenodo Digital Repository: http://doi.org/10.5281/zenodo.3587961.

\section{RESULTS}

We recorded 27 different fish species in the visual surveys (Tab. 1), of which 21 in the Lake, 25 in the Plant and 20 in the Rock habitat. In the RUVs, we recorded 23 fish species encompassing $85 \%$ of the richness found in the visual surveys. These habitats also differed considerably in their benthic composition, with habitat alone explaining over $58 \%$ of the benthic variability observed among samples (Permanova $\mathrm{F}=27 ; \mathrm{R}^{2}=$ $0.58 ; \mathrm{p}<0.01$; Fig. 2a).

Fish community structure varied among habitats both in terms of abundance ( $\mathrm{F}=$ 26.44; $\mathrm{R}^{2}=0.66 ; \mathrm{p}<0.01$; Fig. $\left.2 \mathrm{~b}\right)$ and biomass $\left(\mathrm{F}=3.07 ; \mathrm{R}^{2}=0.18 ; \mathrm{p}<0.01\right.$; Fig. 2c). Samples from the Lake habitat tended to group in the PCoA, mainly due to patterns of abundance and particularly driven by large numbers of Odontostilbe pequira (Steindachner, 1882). This species dominated species abundance in the Lake, but not in the other two habitats (Fig. 2b). Conversely, the biomass structure was not clearly distinct among habitats (Fig. 2c). Fish abundance and biomass were the variables that better explained the variation of agonistic and feeding interactions, respectively, among habitats (Tab. 2).

In $420 \mathrm{~min}$ of video, we counted a total of 12,364 bites on the substratum (approximately $87 \%$ on the Rock, $10 \%$ Lake and $3 \%$ on the Plant habitat), performed by 18 species (Fig. 3). In the Rock habitat, nine species were recorded feeding on the substratum. Prochilodus lineatus (Valenciennes, 1837) alone was responsible for $58 \%$ of the total feeding pressure (Fig. 3). The grazing periphytivores Ancistrus spp. and Parodon nasus Kner, 1859 were only recorded feeding in this habitat. In the Lake 

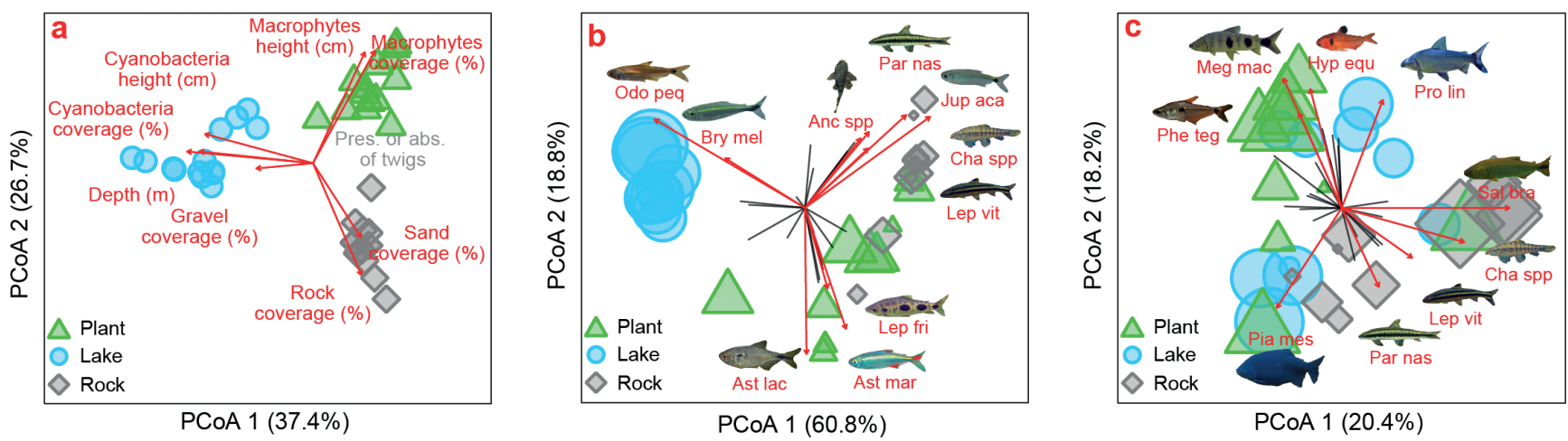

FIGURE 2 I A. Principal coordinate analysis (PCoA) showing ordination of samples according to substratum composition (i.e., habitat categorization); B. PCoA performed with the abundance of fishes, points sized according to the sum of the abundance in the sample (logarithm scaled for better visualization); C. PCoA performed with the biomass of fishes, points sized according to the sum of the biomass in the sample (logarithm scaled for better visualization). Red lines indicate significative variables $(\mathrm{p}<0.05)$ while black lines nonsignificative. Anc spp = Ancistrus spp., Ast lac = Astyanax lacustris, Ast mar = Astyanax marionae, Bry mel = Bryconops melanurus, Cha spp = Characidium spp., Hyp equ = Hyphessobrycon eques, Jup aca = Jupiaba acanthogaster, Lep vit = Leporellus vittatus, Lep fri $=$ Leporinus friderici, Meg $\mathrm{mac}=$ Megaleporinus macrocephalus, Odo peq $=$ Odontostilbe pequira, Par nas = Parodon nasus, Phe teg = Phenacogaster tegatus, Pia mes $=$ Piaractus mesopotamicus, Pro lin = Prochilodus lineatus, Sal bra = Salminus brasiliensis .

TABLE 2 I Output of GLM evaluating the influence of habitat, trophic group and abundance/biomass over the feeding pressure performed by the fishes on the benthic substratum and agonistic interactions among fishes.

\begin{tabular}{l|c|c|c|}
\multicolumn{1}{c|}{ Feeding pressure } & df & F & p value \\
\hline Habitat & 2 & 3.917 & 0.027 \\
\hline Functional group & 7 & 2.001 & 0.076 \\
\hline Biomass & 1 & 30.503 & $<0.001$ \\
\hline \multicolumn{1}{|c|}{ Agonistic interactions } & df & F & p value \\
\hline Habitat & 2 & 0.668 & 0.519 \\
\hline Functional group & 5 & 0.191 & 0.964 \\
\hline Abundance & 1 & 44.785 & $<0.001$ \\
\hline
\end{tabular}

habitat, seven species were recorded feeding on the substratum, with the picking omnivore Odontostilbe pequira feeding in all the samples and responsible for $\sim 53 \%$ of the total feeding pressure. In the Plant habitat, 11 species were detected feeding on the substratum, with the highest feeding pressure performed by two species: the digging omnivore, Megaleporinus macrocephalus (Garavello, Britski, 1988), responsible for 51\% of the total feeding pressure; and the browsing herbivore, Brycon hilarii (Valenciennes, 1850), responsible for $\sim 44 \%$ (Fig. 3). The structure of feeding pressure varied among habitats in terms of both species $\left(\mathrm{F}=4.88 ; \mathrm{R}^{2}=0.21 ; \mathrm{p}<0.01\right)$ and trophic groups $(\mathrm{F}=$ 4.74; $\left.\mathrm{R}^{2}=0.20 ; \mathrm{p}<0.01\right)$. There was higher similarity among samples from the same habitat than between samples from different habitats, particularly in the Rock habitat (Fig. 4). 


\section{Feeding pressure (bites $\bullet \mathrm{kg} / 2 \mathrm{~m}^{2} \cdot 10 \mathrm{~min}$ )}

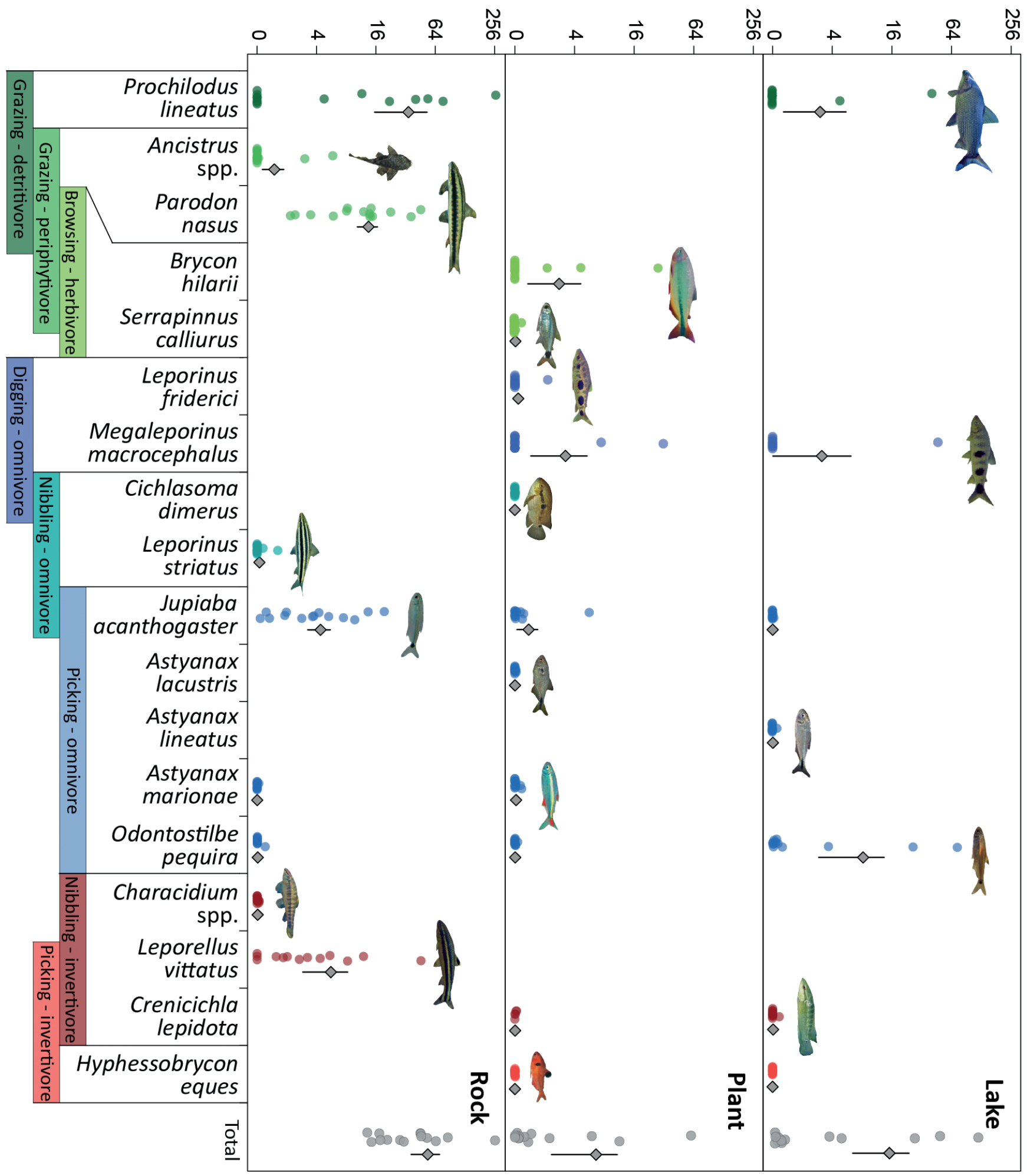

FIGURE 3 I Feeding pressure of the 18 fishes that bit the substratum, and their respective trophic groups (colours) at the Olho d'Água River. Black diamonds and lines represent the mean \pm standard error, respectively. Habitats in which certain species did not fed on the substratum (zero values) are not represented in the graph. The Y-axis scale is $\log _{10}$-transformed to better show data dispersion. 

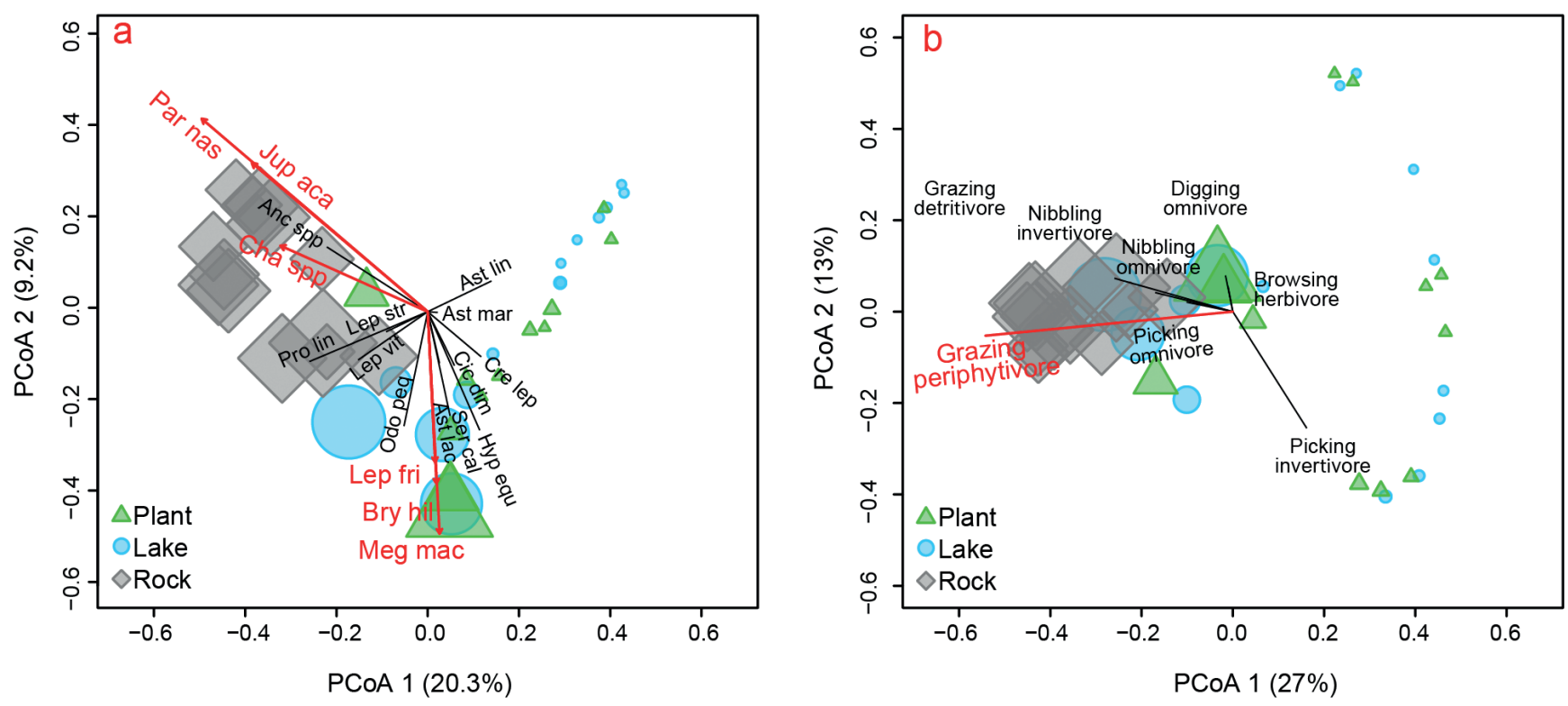

FIGURE 4 I Principal coordinate analysis (PCoA) and permutational analysis of variance (PERMANOVA) to demonstrate feeding pressure variation among habitats accounting for $\mathbf{A}$. species and $\mathbf{B}$. trophic groups, points sized according to the sum of the feeding pressure in the sample (logarithm scaled for better visualization). Red lines indicate significative variables $(\mathrm{p}<0.05)$ while black lines non-significative. Anc spp = Ancistrus spp., Ast lac = Astyanax lacustris, Ast lin = Astyanax lineatus, Ast mar = Astyanax marionae, Bry hil = Brycon hilarii, Cha spp = Characidium spp., Cic dim = Cichlasoma dimerus, Cre lep = Crenicichla lepidota, Hyp equ = Hyphessobrycon eques, Jup aca = Jupiaba acanthogaster Lep fri = Leporinus friderici, Meg mac = Megaleporinus macrocephalus, Lep str = Leporinus striatus, Lep vit = Leporellus vittatus, Odo peq = Odontostilbe pequira, Par nas = Parodon nasus, Pro lin = Prochilodus lineatus, Ser cal = Serrapinnus calliurus.

We counted 1,420 agonistic interactions involving 15 species (approximately 57\% occurred in the Lake, $27 \%$ in the Plant and $16 \%$ in the Rock habitat). The structure of these interactions varied among habitats, with ten species interacting in the Plant habitat, nine species in Rock and six in Lake (Fig. 5). Intraspecific interactions were more frequent than interspecific interactions, especially for the most abundant species (Fig. 5). In the Lake and Plant habitats, O. pequira was responsible for most of the agonistic interactions, targeting almost all the species observed (approximately 93\% of the total of agonistic interactions in the Lake and $77 \%$ in the Plant, Fig. 5). This species was, thus, central to the species interaction network of these two habitats. In the Rock habitat, however, Jupiaba acanthogaster (Eigenmann, 1911) was responsible for approximately $51 \%$ of the agonistic interactions. This species was chased by Parodon nasus with high frequency.

\section{DISCUSSION}

To our knowledge, our study is the first to quantify the degree of variability in fish interactions among different habitats in a tropical clearwater river. Moreover, it also emphasizes the overwhelming role of community structure and habitat variability in defining the intensity, species and trophic composition of feeding and agonistic 
Lake

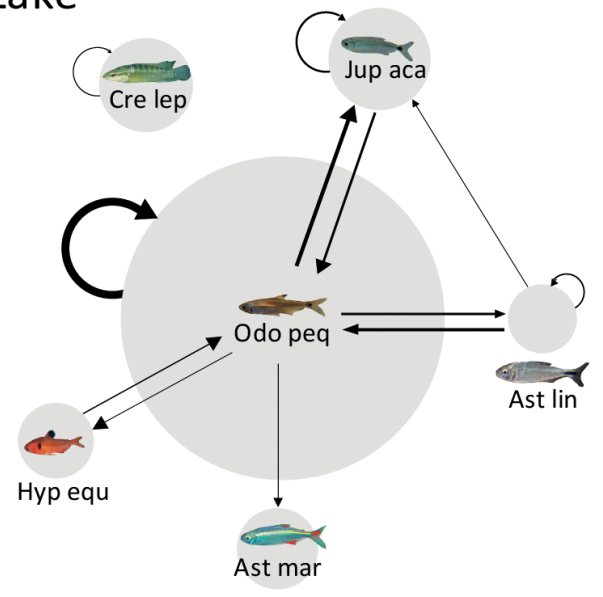

\section{Rock}
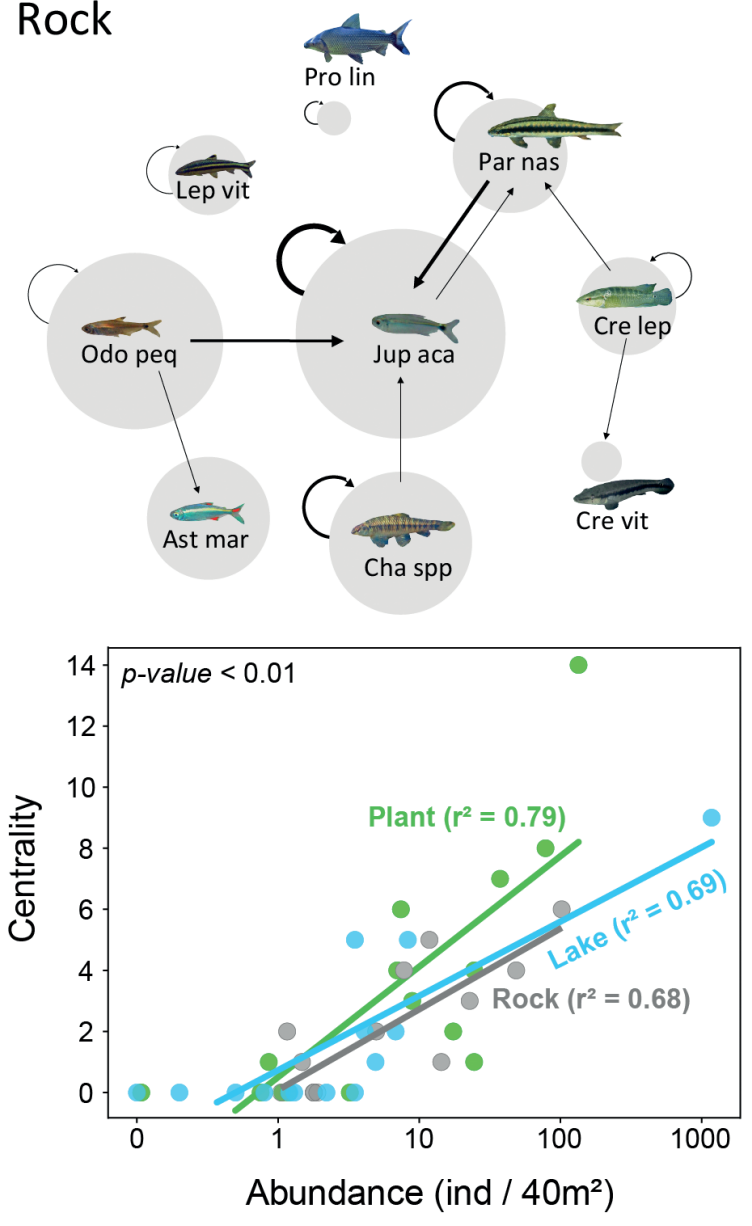
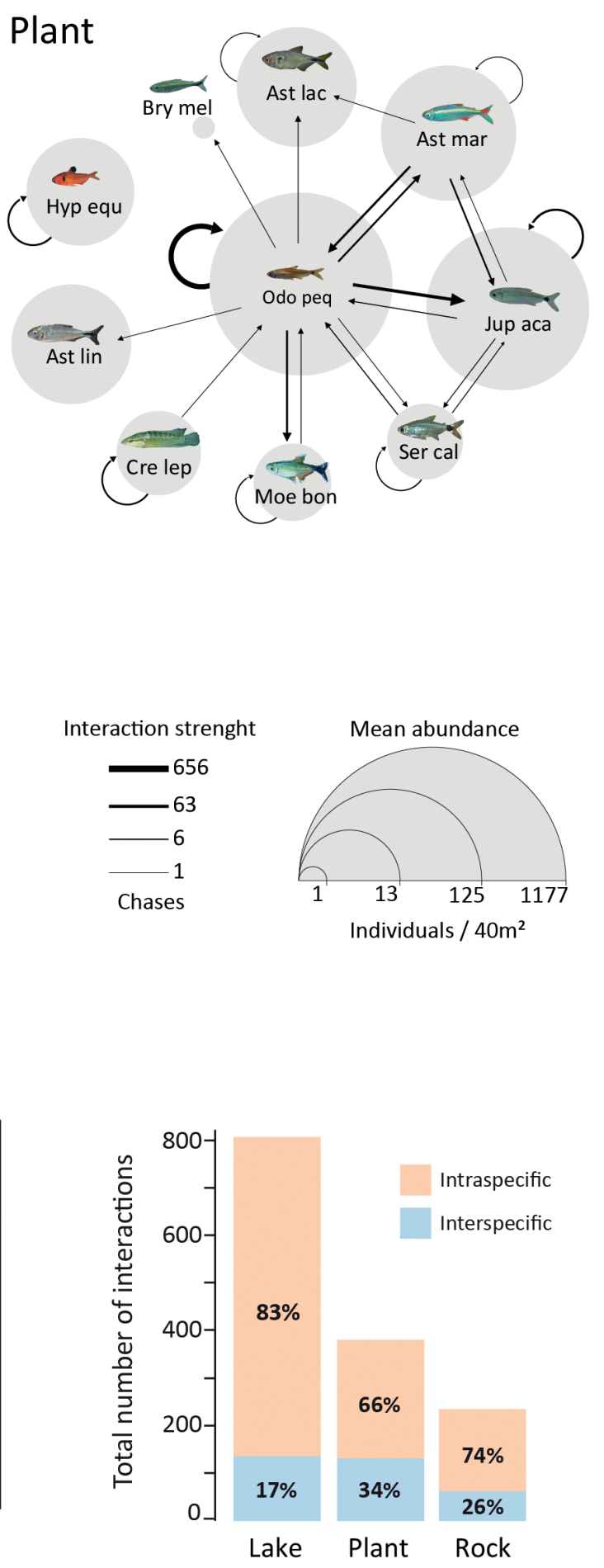

FIGURE 5 I Agonistic interactions between fishes in three habitats of the Olho d'Água River, upper Paraguay River basin, Brazil. Arrow thickness is proportional to agonistic interaction intensity in all three habitats; grey circles are proportional to the mean abundance of each species. Ast lac = Astyanax lacustris, Ast lin = Astyanax lineatus, Ast mar = Astyanax marionae, Bry mel = Bryconops melanurus, Cha spp = Characidium spp., Cre lep = Crenicichla lepidota, Cre vit = Crenicichla vittata, Hyp equ = Hyphessobrycon eques, Jup aca = Jupiaba acanthogaster, Lep vit $=$ Leporellus vittatus, Moe bon = Moenkhausia bonita, Odo peq $=$ Odontostilbe pequira, Par nas = Parodon nasus, Pro lin = Prochilodus lineatus, Ser cal = Serrapinnus calliurus. 
interactions. While the Rock habitat concentrated most of the feeding interactions with the substratum, particularly due to periphytivorous fishes, most of the agonistic interactions occurred in the Lake habitat, led by abundant small characins. The Plant habitat, which has a higher structural complexity compared to the two other habitats, hosted substantially less feeding and agonistic interactions, although these interactions involved more species (especially small characins fishes). Altogether, these findings suggest that these habitats deliver different functions for the local fish community.

The highest feeding pressure observed in the Rock habitat is likely associated to periphyton that overgrows trunks and rock surfaces in this habitat (Power, 1983). Fishes that fed on the Rock habitat, such as Prochilodus lineatus and Ancistrus spp. have morphological adaptations that allow them to scrape periphyton and detritus deposited on solid surfaces (Bowen, 1983). They sort materials through their gills, retaining algae and detritus while eliminating the sediments (Bowen, 1983; Fugi et al., 1996). Detritus and periphyton are abundant food resources in tropical freshwater systems, characterized by high turnover rates (Bowen, 1983; Power, 1983). The River Continuum concept predicts that periphyton growing on rocks would be available as a food resource for upstream river communities whereas detritus would be more important for downstream communities (Vannote et al., 1980). However, similarly to other tropical lowland river systems, our system cannot be clearly distinguished in upstream and downstream communities: rocks and trunks occupy patches alongside a sandy matrix along most of the river extension. Thus, rocky habitats provide detritivores and periphytivores with abundant food sources that are likely critical in terms of energy flow and nutrient cycling for the whole system (Bowen, 1983; Power, 1983; Prejs, 1984; Lodge, 1991; Taylor et al., 2006; Winemiller et al., 2006). For instance, it has been shown elsewhere that a related species, Prochilodus mariae Eigenmann, 1922, is a keystone species modulating organic carbon transport along with a lowland river system in Venezuela (Taylor et al., 2006).

Contrary to the Rock habitat, the Plant habitat featured a high cover of macrophytes, but not periphyton. In this habitat, aquatic plants are routinely consumed, cropped by the scissor-like teeth of Brycon hilarii, which also ingests fruits and insects from the riparian vegetation (Sabino, Sazima, 1999). Additionally, the digging omnivore M. macrocephalus feeds largely on invertebrates buried among macrophytes' roots by digging through the soft substrate or among branches with their snout (Sazima, 1986; Albrecht, Caramaschi, 2003). Brycon hilarii and M. macrocephalus, thus, employ behavioural strategies to exploit resources that are abundant in this habitat. In the Lake habitat, most of the feeding pressure performed by O. pequira occurred in the context of a "feeding frenzy", which consisted in large groups feeding on masses of benthic cyanophytes that become detached from the sand substrate. These blue-green algae seem to be detached during the daylight as a function of oxygen bubbles forming from photosynthetic activity. Since these feeding frenzies did not occur unless the cyanophytes got detached from the substratum, we suspect that $O$. pequira were targeting small invertebrates that inhabit the meandering structure of cyanophyte filaments (Dias, 2007). Small-sized characins are conspicuous components of Neotropical rivers and are essentially known for their versatility in feeding behaviour. They feed over the bottom, water column, surface, and target mucus and scales of other fishes (Sazima, 1983; Lima et al., 2012; Brejão et al., 2013). As such, they dominate trophic links in Neotropical river food webs, also serving as a primary food for predators (Bozza, Hahn, 2010). 
Interspecific agonistic interactions were mostly associated with small-sized characin fishes and the territorial P. nasus. Particularly, two characins, O. pequira and J. acanthogaster, comprised most of the agonistic interactions. These species not only interacted with most of the species within each network, but also performed or received the largest number of agonistic interactions. The centrality of $O$. pequira in the networks of the Lake and Plant habitats and J. acanthogaster in the Rock habitat was a product of the high abundance of this species in these habitats. Density-dependence leads to intense competitive interactions in many organisms, including reef fishes (Bonin et al., 2015). We believe that competition for shelter could account for the observed pattern, since leaves and branches of the macrophytes banks in tropical rivers attain high structural complexity and are intensely used by small characins to shelter from predators (Werner et al., 1977; Savino, Stein, 1989; Suarez et al., 2013). The main predators to which these fish are exposed in daylight are visually oriented birds and predatory fishes such as Salminus brasiliensis (Cuvier, 1816).

Most of the interspecific agonistic interactions in the Rock habitat involved P. nasus and $J$. acanthogaster. Parodon nasus chased J. acanthogaster with high frequency, likely as a result of defence of feeding territories. Feeding territories in tropical freshwater fishes have rarely been detected, particularly in comparison to other systems in which this strategy is common, such as reef systems (Sazima, 1988; Barlow, 1993; Silva et al., 2009). However, there is evidence that this species establishes feeding territories: 1) it has small home ranges, spending much time on patrol, chasing and feeding, as was also observed by Silva et al. (2009); 2) this fish feeds on the bottom with high frequency and intensity in the Rock habitat, where it is abundant, and remains in the same area for long periods of time (as revealed by the remote videos); 3) it chased mostly J. acanthogaster, an abundant species that also feeds frequently over the same substratum, presumably targeting a similar set of resources (periphyton over the rocks).

In this study, we present evidence that fish interactions in a tropical river depend largely on patterns of fish abundance/biomass, but also, to some extent on particularities of habitat. These factors were decisive in the intensity and structure of feeding and agonistic interactions among the sampled habitats and can also contribute to understanding patterns of fish species distribution in other tropical rivers. We demonstrated the importance of quantitatively understanding fish intra- and interspecific interactions while considering the heterogeneity of the environment. This reinforces the logical conclusion that keeping habitat heterogeneity in tropical rivers, for example by controlling anthropogenic impacts and preserving the riparian forest, is essential to maintaining the structure of species interactions and likely also ecosystem functions.

\section{ACKNOWLEDGEMENTS}

We appreciate the logistic support and research permit provided by Eduardo F. Coelho and Luiza Coelho from the RPPN Cabeceira do Prata and the Recanto Ecológico Rio da Prata. We thank Carlos E. L. Ferreira, Cristina Sazima, Débora Ferrari, Fabrício Teresa, Ivan Sazima, Max Levy and Heriberto Gimênes Jr. for support and scientific discussions in the field. The present study is part of the project "Impact of ichthyofauna on benthic communities: latitudinal gradient in reef environments along the Brazilian 
coast and comparisons with freshwater systems" (CNPq 571295/2008-8 granted to SRF). We also thank the Projeto Peixes de Bonito, Programa Biota-MS, and Programa de Pós-graduação em Ecologia-UFSC for essential financial support. This paper is also a product of the first author master's thesis funded by a scholarship from CAPES (code 001), Brazilian Ministry Educational Council.

\section{REFERENCES}

- Albrecht MP, Caramaschi EP. Feeding ecology of Leporinus friderici (Teleostei; Anostomidae) in the upper Tocantins River, Central Brazil, before and after Installation of a hydroelectric plant. Stud Neotrop Fauna Environ. 2003; 38(1):33-40. http://doi.org/10.1076/snfe.38.1.33.14033

- Baber MJ, Babbitt KJ. Influence of habitat complexity on predator-prey interactions between the fish (Gambusia holbrooki) and tadpoles of Hyla squirella and Gastrophryne carolinensis. Copeia. 2004; 2004(1):173-77. http://doi.org/10.1643/CE-03-056R1

- Balassa GC, Fugi R, Hahn NS, Galina AB. Dieta de espécies de Anostomidae (Teleostei, Characiformes ) na área de influência do reservatório de Manso, Mato Grosso, Brasil. Iheringia Sér. Zool. 2004; 94(1):77-82. http://dx.doi.org/10.1590/ S0073-47212004000100014

- Baptiste A. gridExtra: miscellaneous functions for "grid" graphics. 2017. R package version 2.3.

- Barlow GW. The puzzling paucity of feeding territories among freshwater fishes. Mar Behav Physiol. 1993; 23(1-4):155-74. http://doi. org/10.1080/10236249309378863

- Batista-Silva VF, Bailly D, Kashiwaqui EAL, Abelha MCF, Graça WJ. Lengthweight relationships for 55 freshwater fish species from the Iguatemi River, Upper Paraná River basin, Brazil. J Appl Ichthyol. 2015; 31(1):257-60. http://doi.org/10.1111/ jai.12654

- Bell SS, McCoy ED, Mushinsky HR. Habitat structure: the physical arrangement of objects in space. Florida: St Edmundsbury Press Ltd; 1991.

- Benedito-Cecilio E, Agostinho AA, Velho RCC-M. Length-weight relationship of fishes caught in the Itaipu Reservoir, Parana, Brazil. Naga, the ICLARM Quarterly. 1997; 20:57-61.
- Bergman DA, Moore PA. Field observations of intraspecific agonistic behavior of two crayfish species, Orconectes rusticus and Orconectes virilis, in different habitats. Biol Bull. 2003; 205(1):26-35. http://doi. org/10.2307/1543442

- Bonin MC, Boström-Einarsson L, Munday PL, Jones GP. The prevalence and importance of competition among coral reef fishes. Annu Rev Ecol Evol Syst. 2015; 46:169-90. http://doi.org/10.1146/annurevecolsys-112414-054413

- Bozza NA, Hahn NS. Uso de recursos alimentares por peixes imaturos e adultos de espécies piscívoras em uma planície de inundação neotropical. Biota Neotrop. 2010; 10(3):217-26. http://doi.org/10.1590/ S1676-06032010000300025

- Bowen SH. Detritivory in neotropical fish communities. Environ Biol Fishes. 1983; 9(2):137-44. http://doi.org/10.1007/ BF00690858

- Brejão GL, Gerhard P, Zuanon J. Functional trophic composition of the ichthyofauna of forest streams in eastern Brazilian Amazon. Neotrop Ichthyol. 2013; 11(2):361-73. http://doi.org/10.1590/S167962252013005000006

- Camera BF, Evellin N, Silva LR, Godoy DS, Bessa E. Autoecologia de Astyanax marionae (Characiformes, Characidae) em riachos de cabeceira. In: III Biota Meio Ambiente. Universidade do estado de Mato Grosso, Tangará da serra. 2014; p.28-32.

- Carniatto N, Fugi R, Thomaz SM. Highly segregated trophic niche of two congeneric fish species in Neotropical floodplain lakes. J Fish Biol. 2016; 90(3):1118-25. http://doi. org/10.1111/jfb.13236 
- Casatti L, Mendes HF, Ferreira KM. Aquatic macrophytes as feeding site for small fishes in the Rosana reservoir, Paranapanema River, Southeastern Brazil. Brazilian J Biol. 2003; 63(2):213-22. http:// doi.org/10.1590/S1519-69842003000200006

- Casatti L, Ferreira CP, Langeani F. A fishbased biotic integrity index for assessment of lowland streams in southeastern Brazil. Hydrobiologia. 2009; 623:173-89. http://doi. org/10.1007/s10750-008-9656-X

- Cetra M, Rondineli GR, Souza UP. Compartilhamento de recursos por duas espécies de peixes nectobentônicas de riachos na bacia do rio Cachoeira (BA). Biota Neotrop. 2011; 11(2):87-95. http://doi. org/10.1590/S1676-06032011000200010

- Corrêa F, Silva GC. Hábito alimentar de Astyanax asuncionensis (Géry, 1972) durante um período de seca e cheia, no Córrego do Onça, Coxim, Mato Grosso do Sul. Rev Bras Bioci. 2010; 8(4):368-72.

- Coull BC, Wells JBJ. Refuges from fish predation: experiments with phytal meiofauna from the New Zealand rocky intertidal. Ecology. 1983; 64(6):1599-609. http://doi.org/10.2307/1937513

- Crowder LB, Cooper WE. Habitat structural complexity and the interaction between bluegills and their prey. Ecology. 1982; 63(6):1802-13. http://doi. org/10.2307/1940122

- Curio E. The ethology of predation. Berlin: Springer Berlin Heidelberg; 1976.

- Dias TS. Estudo da dieta de oito espécies da subfamília Cheirodontinae (Characiformes: Characidae) em diferentes sistemas lacustres nos estados do RN e RS. [MSc thesis]. Rio Grande do Sul, RS: Universidade Federal do Rio Grande do Sul; 2007.

- Ebner BC, Morgan DL. Using remote underwater video to estimate freshwater fish species richness. J Fish Biol. 2013; 82(5):1592-612. http://doi.org/10.1111/ jfb.12096

- Ebner BC, Fulton CJ, Cousins S, Donaldson JA, Kennard MJ, Meynecke JO et al. Filming and snorkelling as visual techniques to survey fauna in difficult to access tropical rainforest streams. Mar Freshw Res. 2015; 66(2):120-26. http://doi.org/10.1071/MF13339

- Fiori LF, Alves GHZ, Hahn NS, Benedito E. Influence of feeding plasticity on the fitness of small Neotropical characids. Iheringia. 2016; 106:1-6. http://doi. org/10.1590/1678-4766e2016006
- Fox J, Weisberg S. An $\{\mathrm{R}\}$ companion to applied regression. Thousand Oaks: Sage; 2011.

- Fugi R, Hahn NS, Agostinho AA. Feeding styles of five species of bottom-feeding fishes of the high Paraná River. Environ Biol Fishes. 1996; 46:297-307. http://doi. org/10.1007/BF00005006

- Gandini CV, Boratto IA, Fagundes DC, Pompeu PS. Estudo da alimentação dos peixes no rio Grande à jusante da usina hidrelétrica de Itutinga, Minas Gerais, Brasil. Iheringia. 2012; 102(1):56-61. http:// doi.org/10.1590/S0073-47212012000100008

- Gibran FZ, Ferreira KM, Castro RMC. Diet of Crenicichla britskii (Perciformes: Cichlidae) in a stream of Rio Aguapeí basin, Upper Rio Paraná system, southeastern Brazil. Biota Neotrop. 2001; 1(1-2):1-5. http://doi.org/10.1590/S167606032001000100007

- Godoi DS. Diversidade e hábitos alimentares de peixes de um córrego afluente do rio Teles Pires, Carlinda, MT, drenagem do rio Tapajós. [Master Dissertation]. Jaboticabal: Universidade Estadual Paulista. 2004. Available from: https://repositorio.unesp.br/ handle/11449/144151

- Gorman OT, Karr JR. Habitat structure and stream fish communities. Ecology. 1978; 59(3):507-15. http://doi. org/10.2307/1936581

- Gubiani EA, Gomes LC, Agostinho AA. Length-length and length-weight relationships for 48 fish species from reservoirs of the Paraná state, Brazil. Lakes Reservoirs. 2009; 14(4):289-99. http://doi. org/10.1111/j.1440-1770.2009.00411.x

- Ibañez C, Tedesco PA, Bigorne R, Hugueny B, Pouilly M, Zepita C, Zubieta J, Oberdorff T. Dietary-morphological relationships in fish assemblages of small forested streams in the Bolivian Amazon. Aquat. Living Resour. 2007; 20(2):131-42. http://doi.org/10.1051/alr:2007024

- King AJ, George A, Buckle DJ, Novak PA, Fulton CJ. Efficacy of remote underwater video cameras for monitoring tropical wetland fishes. Hydrobiologia. 2018; 807(1):145-64. http://doi.org/10.1007/ s10750-017-3390-1

- Lemon J. Plotrix: a package in the red light district of R. R-News. 2006; 6:8-12. 
- Lima MRL, Bessa E, Krinski D, Carvalho LN. Mutilating predation in the Cheirodontinae Odontostilbe pequira (Characiformes: Characidae). Neotrop Ichthyol. 2012; 10(2):361-68. http://doi. org/10.1590/S1679-62252012000200011

- Lodge DM. Herbivory on freshwater macrophytes. Aquat Bot. 1991; 41(13):195-224. https://doi.org/10.1016/03043770(91)90044-6

- Longo GO, Floeter SR. Comparison of remote video and diver's direct observations to quantify reef fishes feeding on benthos in coral and rocky reefs. J Fish Biol. 2012; 81(5):1773-80. http://doi. org/10.1111/j.1095-8649.2012.03441.x

- Longo GO, Ferreira CEL, Floeter SR. Herbivory drives large-scale spatial variation in reef fish trophic interactions. Ecol Evol. 2014; 4(23):4553-66. http://doi. org/10.1002/ece3.1310

- Longo GO, Morais RA, Martins CDL, Mendes TC, Aued AW, Cândido DV et al. Between-habitat variation of benthic cover, reef fish assemblage and feeding pressure on the benthos at the only atoll in south Atlantic: Rocas Atoll, NE Brazil. PLoS One. 2015; 10(6):e0127176. http://doi. org/10.1371/journal.pone.0127176

- Manço DG, Pivatto MAC. Diagnóstico e plano de manejo da reserva particular do patrimônio natural (RPPN) da fazenda cabeceira do Prata. Programa de Incentivo às Reservas Particulares do Patrimônio Natural do Pantanal; 2007.

- Morais RA, Ferreira CEL, Floeter SR. Spatial patterns of fish standing biomass across Brazilian reefs. J Fish Biol. 2017; 91(6):1642-67. https://doi.org/10.1111/ jfb.13482

- Moss B. Ecology of fresh waters: a view for the twenty-first century. 4th edition. Nova Jersey: Wiley-Blackwell; 2010.

- Novakowski GC, Hahn NS, Fugi R. Diet seasonality and food overlap of the fish assemblage in a pantanal pond. Neotrop Ichthyol. 2008; 4(4):567-76. http://doi. org/10.1590/S1679-62252008000400004

- Oliveira Nuñer AP, Zaniboni-Filho E. Length-weight relationships of fish species caught in the Upper Uruguay River, Brazil. J Appl Ichthyol. 2009; 25(3):362-64. http:// doi.org/10.1111/j.1439-0426.2009.01233.x
- Oksanen J, Blanchet FG, Friendly M, Kindt R, Legendre P, McGlinn D et al. Vegan: community ecology package. 2018. R package version 2.4-6.

- Oliveira VA, Loverde-Oliveira SM, Mateus LA, Teixeira-de Mello F. Lengthweight relationships of 26 fish species from the streams of the upper section of the Paraguay River basin (Mato Grosso, Brazil). J Appl Ichthyol. 2014; 31(1):225-27. http:// doi.org/10.1111/jai.12487

- Paula JE, Filho MBM, Bernardino G, Melo JSC, Ferrari VA. Estudo da vegetação relacionada com a alimentação do "pacu" (Colossoma mitrei - Berg 1895) no pantanal mato-grossense. Acta Bot Bras. 1989; 2(1):73-96. http://doi.org/10.1590/S010233061988000300008

- Petry P, Bayley PB, Markle DF. Relationships between fish assemblages, macrophytes and environmental gradients in the Amazon River floodplain. J Fish Biol. 2003; 63(3):547-79. http://doi.org/10.1046/ j.1095-8649.2003.00169.x

- Power ME. Grazing responses of tropical freshwater fishes to different scales of variation in their food. Environ Biol Fishes. 1983; 9(2):103-15. http://doi.org/10.1007/ BF00690856

- Prejs A. Herbivory by temperate freshwater fishes and its consequences. Environ Biol Fishes. 1984; 10(4):281-96. http://doi.org/10.1007/BF00001481

- Ranåker L, Persson J, Jönsson M, Nilsson PA, Brönmark C. Piscivore-prey fish interactions: mechanisms behind diurnal patterns in prey selectivity in brown and clear water. PLoS One. 2014; 9(11):e102002. http://doi.org/10.1371/ journal.pone.0102002

- R Core Team. R: A language and environment for statistical computing. 2019.

- Roa-Fuentes CA. Estrutura ecomorfológica e trófica de peixes de riachos: comparação entre ambientes com diferentes graus de conservação e entre bacias hidrográficas. [Master dissertation]; São José do Rio Preto: Universidade Estadual Paulista. 2011. Available from: https://repositorio.unesp. br/handle/11449/87561

- Sabino J, Sazima I. Association between fruit-eating fish and foraging monkeys in western Brazil. Ichthyol Explor Freshw. 1999; 10(4):309-12. 
- Sabino J, Zuanon J. A stream fish assemblage in central Amazonia: distribution activity patterns and feeding behavior. Ichthyol Explor Freshw. 1998; 8(3):201-10.

- Santos AR, Oliveira FR, Moralles AC. Análise do conteúdo estomacal de Astyanax lineatus (Perugia, 1891) (Characiformes: Characidae), provenientes da Serra da Bodoquena, estado de Mato Grosso do Sul, Brasil. Nucleus. 2009; 6(2):21-32. http://doi. org/10.3738/1982.2278.201

- Savino JF, Stein RA. Behavioural interactions between fish predators and their prey: effects of plant density. Anim Behav. 1989; 37(2):311-21. http://doi. org/10.1016/0003-3472(89)90120-6

- Sazima I. Scale-eating in characoids and other fishes. Environ Biol Fishes. 1983; 9(2):9-23. http://doi.org/10.1007/ BF00690855

- Sazima I. Similarities in feeding behaviour between some marine and freshwater fishes in two tropical communities. J Fish Biol. 1986; 29(1):53-65. http://doi. org/10.1111/j.1095-8649.1986.tb04926.x

- Sazima I. Territorial behaviour in a scaleeating and a herbivorous Neotropical characiform fish. Rev Bras Biol. 1988; 48(2):189-94.

- Silva SE, Assunção WRC, Duca C, Penha J. Cost of territorial maintenance by Parodon nasus (Osteichthyes: Parodontidae) in a Neotropical stream. Neotrop Ichthyol. 2009; 7(4):677-82. http://doi.org/10.1590/ S1679-62252009000400017

- Smith RS, Johnston EL, Clark GF. The role of habitat complexity in community development is mediated by resource availability. PLoS One. 2014; 9(7):e102920. http://doi.org/10.1371/journal. pone.0102920

- Smolders AJP, Hiza MAG, Velde GVD, Roelofs JGM. Dynamics of discharge, sediment transport, heavy metal pollution and Sábalo (Prochilodus lineatus) catches in the lower Pilcomayo River (Bolivia). River Res Appl. 2002; 18(5):415-27. http:// doi.org/10.1002/rra.690

- Souza TSS, Silva SAAR, Bilce JMB. Dieta de Jupiaba acanthogaster (Eingenmann, 1911) em duas sub-bacias do sistema de drenagem do alto Tapajós. Revista de Ciências Agro-Ambientais, Alta FlorestaMT. 2013; 11:33-41.
- Suarez YR, Ferreira FS, Tondato KK. Assemblage of fish species associated with aquatic macrophytes in Porto Murtinho Pantanal, Mato Grosso do Sul, Brazil. Biota Neotrop. 2013; 13(2):182-89. http://doi. org/10.1590/S1676-06032013000200017

- Taylor BW, Flecker AS, Hall Jr RO. Loss of a harvested fish species disrupts carbon flow in a diverse tropical river. Science. 2006; 313(5788):833-36. http://doi. org/10.1126/science.1128223

- Teresa FB, Sazima C, Sazima I, Floeter SR. Predictive factors of species composition of follower fishes in nuclearfollower feeding associations: a snapshot study. Neotrop Ichthyol. 2014; 12(4):913-19. http://doi.org/10.1590/1982-0224-20140041

- Terra BF,Teixeira FK, Rezende CF. Length-weight relationships of 10 freshwater fish species from an intermittent river basin, semi-arid region, Brazil. J Appl Ichthyol. 2017; 33(4):832-34. http://doi.org/10.1111/jai.13357

- Vari RP. Systematics of the neotropical characiform genus Cyphocharax Fowler (Pisces, Ostariophysi). Smithson Contrib Zool. 1992; 529:109-14.

- Vannote RL, Minshall GW, Cummins KW, Sedell JR, Cushing CE. The river continuum concept. Can J Fish Aquat Sci. 1980; 37(1):130-37. https://doi.org/10.1139/ f80-017

- Vázquez DP, Melián CJ, Williams NM, Blüthgen N, Krasnov BR, Poulin R. Species abundance and asymmetric interaction strength in ecological networks. Oikos. 2007; 116(7):1120-27. https://doi. org/10.1111/j.0030-1299.2007.15828.x

- Werner EE, Hall DJ, Laughlin DR, Wagner DJ, Wilsmann LA, Funk FC. Habitat partitioning in a freshwater fish community. J Fish Res Board Can. 1977; 34(3):360-70. http://doi.org/10.1139/f77-058

- Wickham H. Reshaping data with the reshape package. J Stat Softw. 2007; 21(12):1-25. http://doi.org/10.18637/jss. v021.i12

- Wickham H. Ggplot2: elegant graphics for data analysis. New York: Springer-Verlag; 2016. http://doi.org/10.1007/978-0-38798141-3

- Wickham H. Scales: scale functions for visualization. 2017. R package version 0.5.0. 


\section{Neotropical |chthyology}

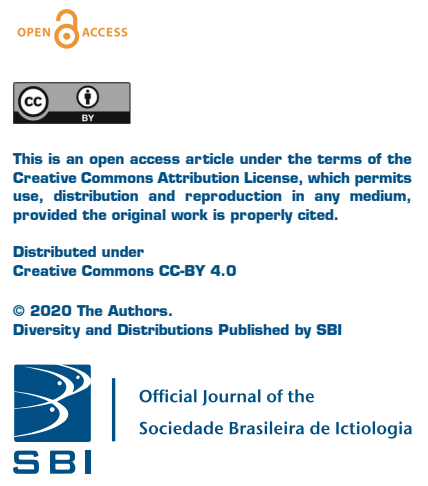

- Winemiller Ko, Montoya JV, Roelke DL, Layman CA, Cotner JB. Seasonally the benthic ecology of a tropical floodplain river. J North Am Benthol Soc. 2006; 25(1):250-62. http://doi.org/10.1899/08873593(2006)25[250:SVIODF]2.0.CO;2 varying impact of detritivorous fishes on
- Zuntini D, Vicentin W, Costa FES, Marques SP, Barboza EG. Alimentação natural da Piraputanga, Brycon hilarii (Teleostei- Characidae) no Rio Miranda, Município de Jardim, MS - Projeto Piracema. In: IV Simpósio sobre recursos naturais e sócio-econômicos do Pantanal. Corumbá/MS. 2004.

\section{AUTHOR CONTRIBUTIONS}

Lucas Teixeira Nunes: Conceptualization, Data curation, Formal Analysis, Investigation, Methodology, Project administration, Resources, Software, Supervision, Validation, Visualization, Writing (original draft), Writing (review \& editing).

Renato Araujo Morais: Conceptualization, Data curation, Formal Analysis, Funding acquisition, Investigation, Methodology, Project administration, Resources, Software, Supervision, Validation, Visualization, Writing (original draft), Writing (review \& editing).

Guilherme Ortigara Longo: Conceptualization, Data curation, Formal Analysis, Funding acquisition, Investigation, Methodology, Project administration, Resources, Software, Supervision, Validation, Visualization, Writing (original draft), Writing (review \& editing).

José Sabino: Conceptualization, Data curation, Formal Analysis, Funding acquisition, Investigation, Methodology, Project administration, Resources, Software, Validation, Visualization, Writing (original draft), Writing (review \& editing).

Sergio Ricardo Floeter: Conceptualization, Data curation, Formal Analysis, Funding acquisition, Investigation, Methodology, Project administration, Resources, Software, Supervision, Validation, Visualization, Writing (original draft), Writing (review \& editing).

\section{ETHICAL STATEMENTS}

Not applicable.

\section{COMPETING INTERESTS}

Not applicable.

\section{HOW TO CITE THIS ARTICLE}

- Nunes LT, Morais RA, Longo GO, Sabino J, Floeter SR. Habitat and community structure modulate fish interactions in a neotropical clearwater river. Neotrop Ichthyol. 2020; 18(1):e190127. https://doi.org/10.1590/1982-0224-2019-0127 
